\title{
CBCT Analysis of Rabbit Temporomandibular Joints With Osteoarthrosis Induced by Monoiodoacetate and Papain
}

\author{
Análisis por TCCB de la Articulación Temporomandibular de Conejos \\ con Osteoartrosis Inducida por Monoiodoacetato y Papaina
}

Nilton Alves ${ }^{1,2,3}$; Ivonne Garay ${ }^{3}$; Naira Deana ${ }^{4} \&$ Marcia Molinett ${ }^{5}$

\begin{abstract}
ALVES, N.; GARAY, I.; DEANA, N. \& MOLINETT, M. CBCT analysis of rabbit temporomandibular joints with osteoarthrosis induced by monoiodoacetate and papain. Int. J. Morphol., 36(2):513-518, 2018.

SUMMARY: Osteoarthrosis (OA) is a degenerative disease characterized by loss of joint cartilage, remodelling of the subchondral bone, narrowing of joint spaces and the formation of osteophytes. Animal models are used to study the mechanisms of OA, as well as to test the effects of anti-osteoarthrosis drugs. The objective of the present study was to determine the changes identifiable by imaging techniques occurring in rabbit temporomandibular joints (TMJ) at 15, 25 and 45 days after OA inducement by monoiodoacetate (MIA) and papain. The imaging technology used was cone-beam computerised tomography (CBCT). The model animals were 22 young adult male New Zealand rabbits, divided randomly into three study groups: Four rabbits in the control group, nine in the papain experimental group and nine in the monoiodoacetate (MIA) experimental group. OA was induced by arthrocentesis in the lower compartment of both TMJs. The rabbits were examined by CBCT at 15, 25 and 45 days after the injection of MIA and papain. The mandibular condyles presented loss of their rounded shape, deformation of the condyle or mandibular fossa, cortical irregularity, cortical wear and changes in the dimensions of the condyle. OA induction by MIA and papain generates changes observable by CBCT in the dimensions of the mandibular condyle in rabbits. Both inducers promote signs compatible with OA on the joint surfaces of the TMJ; MIA promotes more expressive changes.
\end{abstract}

KEY WORDS: Induced osteoarthrosis; Cone-beam computerized tomography; Monoiodoacetate; Papain; Temporomandibular joint.

\section{INTRODUCTION}

Osteoarthrosis $(\mathrm{OA})$ is a degenerative disease characterized by loss of joint cartilage, remodelling of the subchondral bone, narrowing of joint spaces and the formation of osteophytes (Kim et al., 2010). The disease affects the cartilage and the whole joint structure, including the subchondral bone, synovial membrane and joint capsule (Alves et al., 2013). Histopathological studies suggest that the degenerative alterations may be correlated with perforation or deformation of the joint disc (Tollison et al., 2002). The repair process after joint damage involves inflammation, cell proliferation and synthesis of elastic collagen fibres and reticular fibres. The repair of jaw cartilage lesions is a very slow process, with little regenerative capacity compared to other types of connective tissue (Hunziker, 2002).
Animal models are used to study the mechanisms of $\mathrm{OA}$, as well as to test the effects of anti-osteoarthrosis drugs (Cledes et al., 2006). The temporomandibular joint (TMJ) of the rabbit presents morphological similarities to the human TMJ, and there are also similarities in mandibular movements during mastication (Alves et al., 2016). This animal model thus offers significant advantages for TMJ research (Mills et al., 1994). Intra-articular injection of monoiodoacetate is one of the methods used to study OA in animals, since it leads to condrocyte death and triggers a degenerative process (Dowling et al., 2004). Papain, another substance used to induce OA, promotes pathological similarities between OA in the rabbit TMJ and OA in the human TMJ (Yang \& Shi, 2002).

\footnotetext{
${ }^{1}$ Centro de Excelencia en Estudios Morfológicos y Quirúrgicos (CEMyQ), Universidad de La Frontera, Temuco, Chile.

${ }^{2}$ Centro de Investigación en Morfología Aplicada (CIMA), Universidad de La Frontera, Temuco, Chile.

${ }^{3}$ Facultad de Odontología, Universidad de La Frontera, Temuco, Chile.

${ }^{4}$ Programa de Magister en Odontología, Facultad de Odontología, Universidad de La Frontera, Temuco, Chile.

${ }^{5}$ Escuela de Tecnología Médica, Universidad Austral de Chile, Puerto Montt, Chile.

Acknowledgment:Universidad de La Frontera, Dirección de Investigación, Proyecto DI16-0046
} 
Cone-beam computerized tomography (CBCT) is less expensive and requires a lower dose of radiation than conventional CT (Tsiklakis et al., 2004). It provides a threedimensional image of the mineralised maxillofacial tissue with minimal distortion. $\mathrm{CBCT}$ is the imaging technique of choice for evaluating the osseous components of the TMJ. It provides essential information to help in the diagnosis of a variety of TMJ alterations, including osteoarthritis, inflammatory arthritis, trauma and development disorders (Barghan et al., 2012).

The object of the present study was to determine the changes identifiable by cone-beam computerized tomography (CBCT) occurring in the TMJ of rabbits at 15 , 25 and 45 days after inducement of OA by monoiodoacetate and papain.

\section{MATERIAL AND METHOD}

This study was approved by the Scientific Ethics Committee of Universidad de La Frontera (Folio no. 079/ $15)$.

Sample. Young adult male New Zealand rabbits (Oryctolagos Cuniculi L.) were used, aged five months and an average weight between 3 and $4 \mathrm{~kg}$. The sample consisted of 22 rabbits, selected at random and divided into three study groups: four rabbits in a control group (CG), nine in the papain experimental group and nine in the monoiodoacetate (MIA) experimental group.

The rabbits were kept in individual cages with fed ad libitum with water, rabbit pellets and greens. The habitat was kept under an appropriate light cycle, temperature and moisture. The animals were identified by marking their ears with indelible ink, and an identifying plate was affixed to each cage.

OA inducement by MIA. OA was induced by MIA in rabbit TMJs by intra-articular injection of $3 \mathrm{mg}$ of monoiodoacetate dissolved in $50 \mathrm{ml}$ of sterile saline solution, using the arthrocentesis method (Güler et al., 2011). The MIA was administered in a single dose in the lower compartment of the TMJ. To do this a reference point was taken $3 \mathrm{~mm}$ posterior of the anterior crest of the zygomatic process of the temporal bone, which gives access to the joint capsule; the capsule was penetrated by the needle immediately above this reference point and the MIA solution was injected slowly into the intra-articular region.

OA inducement by papain. To induce OA by papain, the same reference points were used as described for inducement by MIA. Papain was administered by arthrocentesis in three doses, on days 1, 4 and 7 , in doses of $0.3 \mathrm{ml}$ of papain solution (1.6\%) (Li et al., 2013; Siebelt et al., 2014).

Control Group. For the control group, five healthy animals with the same physical characteristics as the test animals were examined by CBCT. They received an injection of 50 $\mathrm{ml}$ of saline solution in the lower compartment of the TMJ.

Cone-Beam Computerised Tomography. CBCT examination was carried out in the Dental Clinic of Universidad de La Frontera at 15, 25 and 45 days after injection with papain and MIA. The animals were anesthetized by intramuscular injection of Ketamine $5 \%(20 \mathrm{mg} / \mathrm{kg})$ and Xylazine $(0.1 \mathrm{mg} / \mathrm{kg})$ and the examination was carried out 8 minutes after application of the sedative. Once sedated, the rabbit was placed in a box with four sides - inferior, posterior, and two lateral - such that it was sitting on the inferior surface. Its extremities were tied with tapes to fix it to the posterior side and keep it still. This made examination easier since the animal was immobilized in a position in which its head could be positioned for tomography.

The equipment used was a Vantech brand Pax Zenit 3D dating from 2011. The TMJs were analyzed with a FOV, 8 x $6 \mathrm{~cm}$, voxel size $0.12 \mathrm{~mm}$, exploration time 24 seconds. The data were converted into $3 \mathrm{D}$ images with volume representation using the Ez3D 2009 software. The slice thickness used in this study was $1.0 \mathrm{~mm}$. Once the CBCT images had been obtained, the condyle measurements were analysed in sagittal and coronal sections (Fig. 1). The condyles and mandibular fossa were also analyzed to evaluate the integrity of the TMJ surfaces after OA inducement.

Statistical analysis. Descriptive analysis was by mean measurements with standard deviation. The Shapiro-Wilk test was applied to analyse the normality of the data. The Wilcoxon, Kruskall-Wallis and Mann-Whitney U tests were used; the significance threshold was $5 \%$.

\section{RESULTS}

Table I shows the means found for the mandibular condyle in the sagittal and coronal sections of rabbits with OA induced by MIA and papain. The mean value in the sagittal section of the mandibular condyle in the control group (CG) was $5.0 \mathrm{~mm}$. The experimental groups presented lower mean values than the CG, in TMJs with OA induced by both MIA ( 25 and 45 days) $(\mathrm{p}=0.00)$ and papain $(15,25$ and 45 days) $(\mathrm{p}<0.01)$. 
Table I. Mean and standard deviation found for mandibular condyles of rabbits with OA induced by MIA and papain.

\begin{tabular}{lllll}
\hline & \multicolumn{2}{c}{ Coronal section } & \multicolumn{2}{c}{ Sagittal section } \\
& Mean & SD & Mean & SD \\
\hline MIA group, 15 days & 4.48 & \pm 0.79 & 5.43 & \pm 0.64 \\
MIA group, 25 days & 4.61 & \pm 0.69 & 4.78 & \pm 0.87 \\
MIA group, 45 days & 3.80 & \pm 0.60 & 4.18 & \pm 0.35 \\
Papain group 15 days & 3.88 & \pm 0.54 & 4.25 & \pm 0.44 \\
Papain group 25 days & 4.18 & \pm 0.17 & 4.66 & \pm 0.13 \\
Papain group 45 days & 4.10 & \pm 0.43 & 4.53 & \pm 0.39 \\
\hline
\end{tabular}
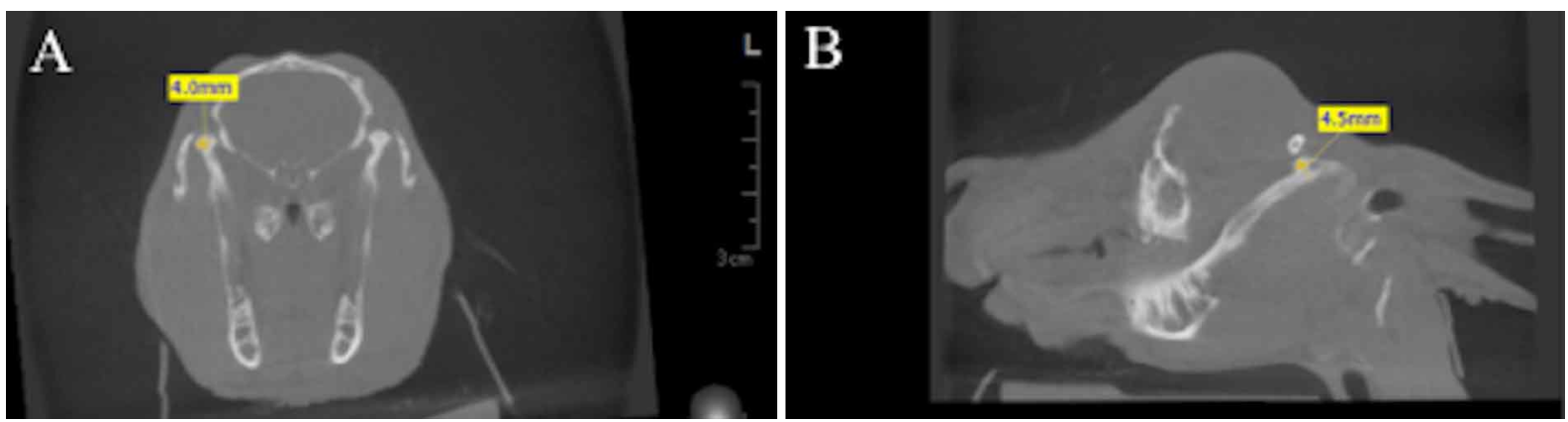

Fig. 1. CBCT image showing the measurement of the right mandibular condyle in coronal (A) and sagittal (B) sections.
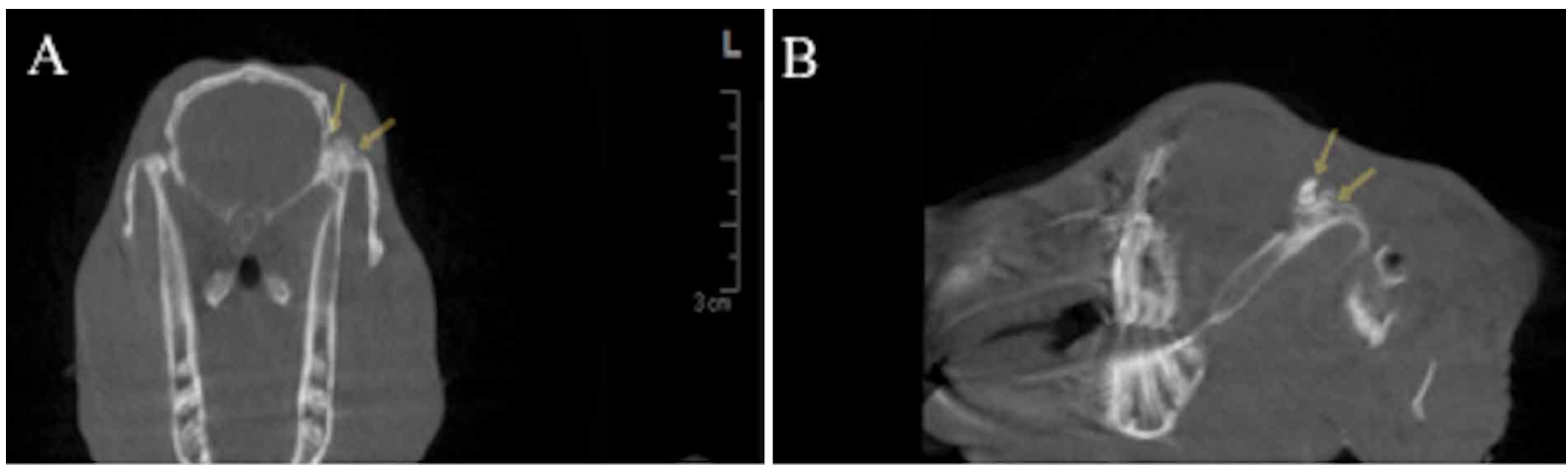

Fig. 2. CBCT images taken 15 days after injection with papain. A. Coronal section of the left condyle: Larger dimensions are observed in the condyle in both vertical and latero-medial planes. Observe the condyle deformation, bone sclerosis (yellow arrows); formation of free bodies and occupation of the joint space (red arrow). B. Sagittal section of the left condyle: Larger dimensions are observed in the condyle in both the vertical and postero-anterior planes. Observe the formation of free bodies and occupation of the joint space (red arrow).
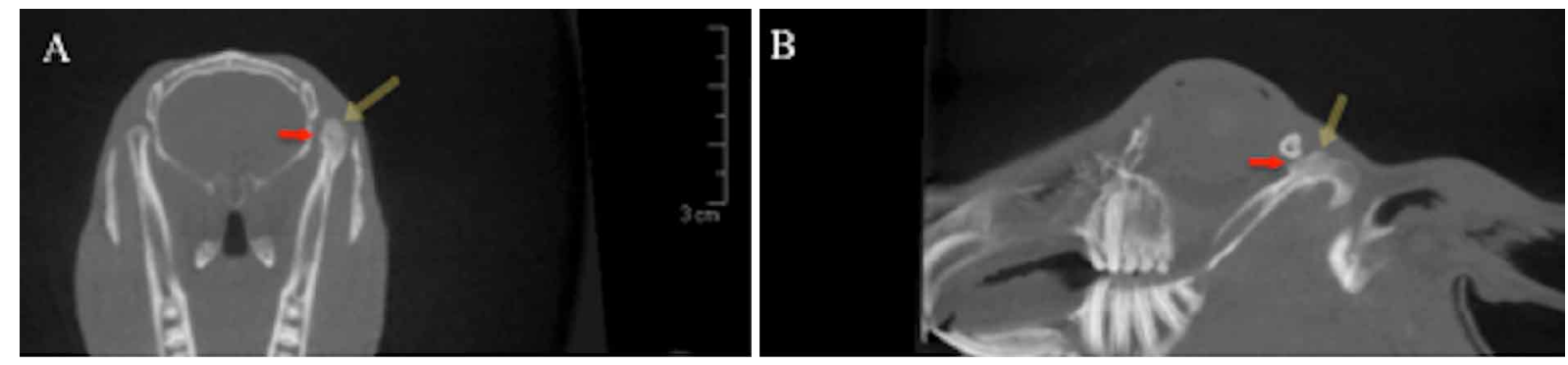

Fig. 3. CBCT image taken 25 days after injection with MIA. A. Coronal section of the left condyle: Larger condyle dimensions are observed in both vertical and latero-medial planes. Observe the condyle deformation and bone sclerosis (yellow arrow). Observe the subchondral cyst in medial pole (red arrow). B. Sagittal section of the left condyle: Larger condyle dimensions are observed in the vertical plane. Observe the irregular cortical and bone sclerosis (yellow arrow). Observe the subchondral cyst (red arrow). 
The mean value found for the MIA group at 45 days was significantly lower than for the MIA group at 15 days $(p=0.015)$. The mean values found for TMJs with OA induced by MIA were higher than those found for those with inducement by papain at 15 days $(\mathrm{p}=0.01)$ and 25 days $(\mathrm{p}=0.01)$.

The mean value in the coronal section of the mandibular condyle in the control group was $4.2 \mathrm{~mm}$. No statistical difference was found for the coronal sections.
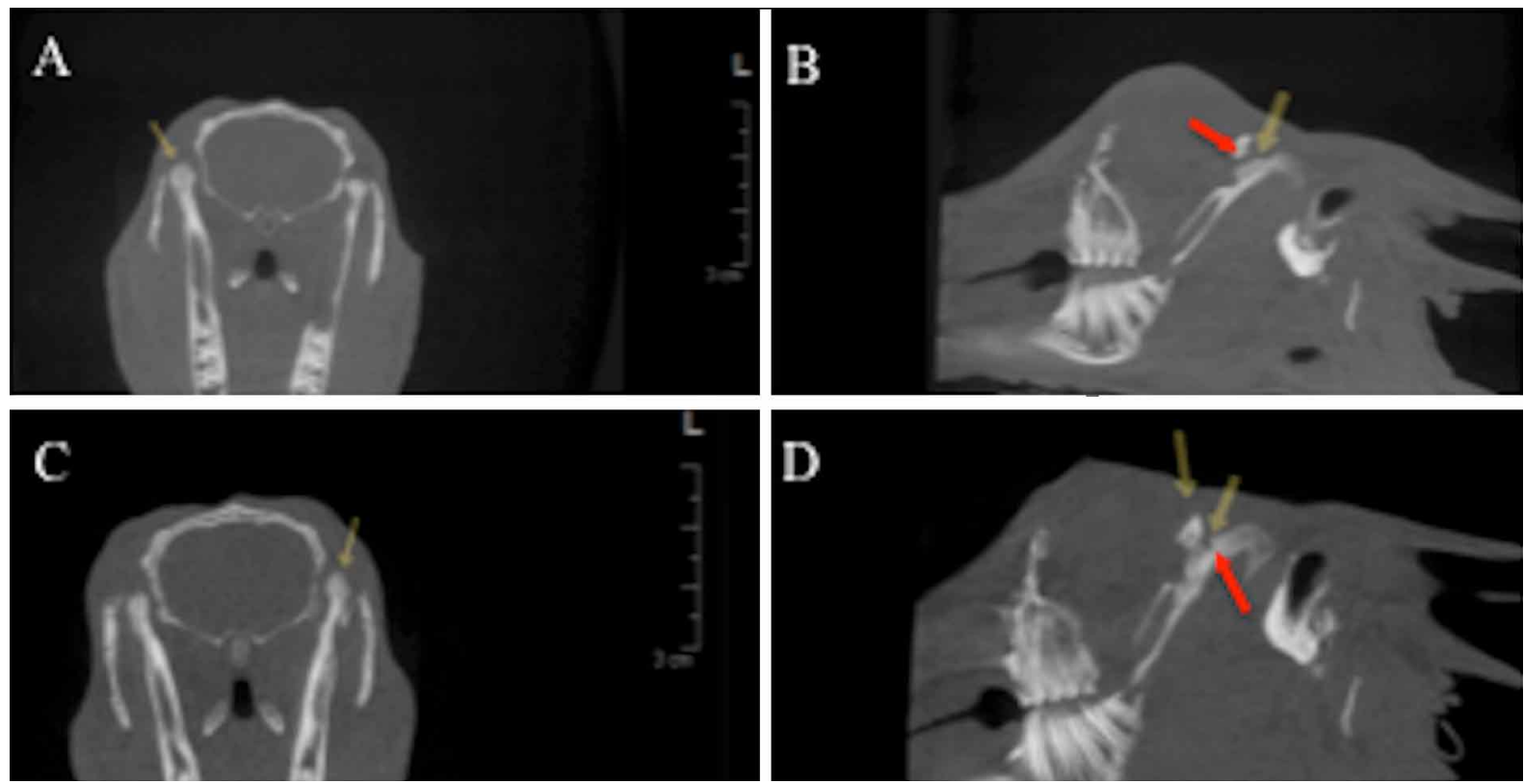

Fig. 4. CBCT image taken 45 days after injection with MIA. A. Coronal section of the right condyle: Larger dimensions are observed in the right mandibular condyle in both vertical and latero-medial planes. Observe the condyle deformation and bone sclerosis (yellow arrow). B. Sagittal section of the right condyle: Larger mandibular condyle dimensions are observed in the vertical plane (yellow arrow). Observe the erosion of the upper cortical, opposite the articular tubercle (red arrow). C. Coronal section of the left condyle: Larger dimensions are observed in vertical plane. Observe the condyle deformation and bone sclerosis (yellow arrow). D. Sagittal section of the left condyle: Larger dimensions are observed in the vertical plane. Observe the irregular cortical, bone sclerosis in the articular tubercle (green arrow) and condyle (yellow arrow). Observe the subchondral cyst in superior pole (red arrow).

\section{DISCUSSION}

$\mathrm{OA}$ is the most frequently-occurring disease in all joints, including the TMJ (Larheim et al., 2015). CBCT examination allows osteophytes, subcortical sclerosis, subcortical cysts, surface erosion, articular surface flattening and generalized sclerosis to be observed in TMJs affected by OA (Ahmad et al., 2009). In the present study we used CBCT to compare two types of chemical OA inducers in rabbit TMJs.
No significant statistical difference was found between sides in any case.

The surface of the condyles with OA induced by papain (15 days) (Fig. 2) and MIA (25 and 45 days) (Figs. 3 and 4 respectively) presented the following effects: deformation of the mandibular condyle and articular tubercle; bone sclerosis; altered dimensions in the condyle (vertical or latero-medial); cortical erosion; presence of osteophytes; presence of subchondral cyst. The alterations were most expressive in TMJs with OA induced by MIA, after 45 days. 
of the mandible in rabbits with OA. In the present study we chose the rabbit as our animal model because the histological and histochemical characteristics of the human and rabbit TMJ present many similarities, including their cell organization and the distribution of Type I and II collagens, proteoglycans and elastin (Savalle et al., 1990; Mills et al.).

Cledes et al. observed that the injection of MIA into the lower compartment of the TMJ in rabbits can produce internal damage accompanied by signs of arthrosis, with thickening and fibrillation of the cartilage and chondrocyte migration in areas where the surface of the subchondral bone was locally destroyed. Furthermore, these authors observed resorption of the subchondral bone, which was gradually replaced by a highly cellular conjunctive tissue. The damage increased over the course of time 10 days after inducement. Forty days after the injection, the subchondral and chondroid bones were exposed in the articular cavity. Güler et al. state that intra-articular injection of MIA by arthrocentesis is an effective, minimally invasive method for reproducing OA in rabbit TMJ, with loss of articular cartilage and lesions which imitate human OA four weeks after inducement.

Yang \& Shi induced OA in rabbit TMJs by papain injection; four weeks after inducement, important degenerative changes were observed, such as extensive destruction of articular cartilage, bone destruction, formation of osteophytes and surface roughening.

In our study using CBCT, we observed changes in the shape of the mandibular condyle from 25 days after MIA injection; the damage was most expressive 45 days after inducement, with a serious alteration in the shape. We also observed the following changes: (i) deformation of the mandibular condyle and articular tubercle; (ii) bone sclerosis; (iii) altered dimensions in the condyle (vertical or lateromedial); (iv) cortical erosion; (v) presence of osteophytes; (vi) presence of subchondral cyst, (vii) signs compatible with OA. Güler et al. used computerised tomography to analyse the changes in rabbit TMJs at 2, 4 and 6 weeks after OA inducement by MIA. These authors found minor abnormalities after four weeks of monitoring and moderate abnormalities after six weeks.

MIA (Cledes et al.; Güler et al.; Artuzi et al., 2016) and papain (Yang \& Shi) have been used successfully to induce OA in rabbit TMJs in previous studies. The severity of the OA is directly related with the exposure time (Cledes et al.) and the concentration of the drug applied (Guingamp et al., 1997; Güler et al.). In our study we used $3 \mathrm{mg}$ of MIA in $50 \mathrm{ml}$ of saline solution, as proposed by Güler et al. who observed lesions predominantly in the central and anterior areas of the joint four weeks after inducement. In their study,
Güler et al. report that the mean volume of the subchondral bone was related with the MIA concentration; it was remarkably reduced when $2.5 \mathrm{mg} / \mathrm{ml}$ and $3 \mathrm{mg} / \mathrm{ml}$ of MIA were used as compared to doses of 1.5 and $2.0 \mathrm{mg} / \mathrm{ml}$. In other studies, Artuzi et al. and Cledes et al., were able to generate degenerative effects in rabbit TMJs using lower doses of MIA (0.5 $\mathrm{mg}$ and $1.5 \mathrm{mg}$ respectively).

\section{CONCLUSIONS}

OA induction by MIA and papain generates changes observable by CBCT in the dimensions of the mandibular condyle in rabbits. Both inducers promote signs compatible with OA on the articular surfaces of the TMJ; MIA promotes more expressive changes. CBCT is an important tool which can be used to monitor the development of chemically induced $\mathrm{OA}$ in rabbits.

ALVES, N.; GARAY, I.; DEANA, N. \& MOLINETT, M. Análisis por TCCB de la articulación temporomandibular de conejos con osteoartrosis inducida por monoiodoacetato y Papaina. Int. J. Morphol., 36(2):513-518, 2018.

RESUMEN: La osteoartrosis (OA) es una enfermedad degenerativa caracterizada por la pérdida de cartílago articular, remodelación ósea subcondral, estrechamiento del espacio articular y formación de osteofitos. El modelo animal es utilizado para estudiar los mecanismos de la OA, así como testar el efecto de drogas anti-osteoartrosis. El objetivo de este estudio fue determinar los cambios imagenológicos, mediante tomografía computarizada cone-beam (TCCB), que se generan en 15, 25 y 45 días, luego de la inducción de OA por medio de Monoiodoacetato (MIA) y Papaína sobre la ATM de conejos. Fueron utilizados 22 conejos machos, adultos jóvenes, de raza New Zealand divididos aleatoriamente en 3 grupos de estudio: 4 conejos para un grupo control, 9 conejos para el grupo experimental con Papaína y 9 conejos para el grupo experimental con monoiodoacetato (MIA). Se realizó la inducción de OA por la técnica de artrocentesis en el compartimiento inferior de ambas ATMs. Se les realizó examen de TCCB en los días 15, 25 y 45 tras la inyección de MIA y de papaina. Los cóndilos mandibulares presentaron pérdida de forma redondeada de cóndilo, deformidad de cóndilo o fosa mandibular, irregularidad de corticales, desgaste de corticales, cambio de dimensiones de cóndilo. La inducción de OA por medio de MIA y papaína genera cambios en la dimensión del cóndilo mandibular de conejos observables a través de TCCB. Además, ambos inductores promueven signos compatibles con OA en las superficies articulares de la ATM, siendo que la MIA promueve cambios más expresivos.

PALABRAS CLAVE: Osteoartrosis inducida; Tomografía computarizada Cone-beam; Monoiodoacetato; Papaína; Articulación temporomandibular. 


\section{REFERENCES}

Ahmad, M.; Hollender, L.; Anderson, Q.; Kartha, K.; Ohrbach, R.; Truelove, E. L.; John, M. T. \& Schiffman, E. L. Research diagnostic criteria for temporomandibular disorders (RDC/TMD): development of image analysis criteria and examiner reliability for image analysis. Oral Surg. Oral Med. Oral Pathol. Oral Radiol. Endod., 107(6):844-60, 2009.

Alves, A. C.; Vieira, R.; Leal-Junior, E.; dos Santos, S.; Ligeiro, A. P.; Albertini, R.; Junior, J. \& de Carvalho, P. Effect of low-level laser therapy on the expression of inflammatory mediators and on neutrophils and macrophages in acute joint inflammation. Arthritis Res. Ther. 15(5):R116, 2013.

Alves, N.; Garay, I. \& Deana, N. F. Effects of Low-Level Laser (Ga-Al-As $904 \mathrm{~nm}$ ) on the mandibular condyle of rabbits: Analysis by cone beam computed tomography. Int. J. Morphol., 34(1):218-222, 2016.

Artuzi, F. E.; Langie, R.; Abreu, M. C.; Quevedo, A. S.; Corsetti, A.; Ponzoni, D. \& Puricelli, E. Rabbit model for osteoarthrosis of the temporomandibular joint as a basis for assessment of outcomes after intervention. Br. J. Oral Maxillofac. Surg., 54(5):e33-7, 2016.

Barghan, S.; Tetradis, S. \& Mallya, S. Application of cone beam computed tomography for assessment of the temporomandibular joints. Aust. Dent. J., 57 Suppl. 1:109-18, 2012.

Cledes, G.; Felizardo, R.; Foucart, J. M. \& Carpentier, P. Validation of a chemical osteoarthritis model in rabbit temporomandibular joint: a compliment to biomechanical models. Int. J. Oral Maxillofac. Surg., 35(11):1026-33, 2006.

Dowling, B. A.; Dart, A. J. \& Matthews, S. M. Chemical arthrodesis of the distal tarsal joints using sodium monoiodoacetate in 104 horses. Aust. Vet. J., 82(1-2):38-42, 2004.

Guingamp, C.; Gegout-Pottie, P.; Phillipe, L.; Terlain, B.; Netter, P. \& Gillet, P. Mono-iodoacetate-induced experimental osteoarthritis: a doseresponse study of loss of mobility, morphology, and biochemistry. Arthritis Rheum., 40(9):1670-9, 1997.

Güler, N.; Kürkçü, M.; Duygu, G. \& Cam, B. Sodium iodoacetate induced osteoarthrosis model in rabbit temporomandibular joint: CT and histological study (part I). Int. J. Oral Maxillofac. Surg., 40(11):128995, 2011.

Hunziker, E. B. Articular cartilage repair: basic science and clinical progress. A review of the current status and prospects. Osteoarthritis Cartilage, 10(6):432-63, 2002

Kim, J. K.; Kim, T. H.; Park, S. W.; Kim, H. Y.; Kim, Sh.; Lee, Sy. \& Lee, S. M. Protective effects of human placenta extract on cartilage degradation in experimental osteoarthritis. Biol. Pharm. Bull., 33(6):1004-10, 2010

Larheim, T. A.; Abrahamsson, A. K.; Kristensen, M. \& Arvidsson, L. Z. Temporomandibular joint diagnostics using CBCT. Dentomaxillofac. Radiol., 44(1):20140235, 2015

Li, X.; Lang, W.; Ye, H.; Yu, F.; Li, H.; Chen, J.; Cai, L.; Chen, W.; Lin, R.; Huang, Y. \& Liu, X. Tougu Xiaotong capsule inhibits the tidemark replication and cartilage degradation of papain-induced osteoarthritis by the regulation of chondrocyte autophagy. Int. J. Mol. Med., 31(6):1349-56, 2013.

Mills, D. K.; Daniel, J. C.; Herzog, S. \& Scapino, R. P. An animal model for studying mechanisms in human temporomandibular joint disc derangement. J. Oral Maxillofac. Surg., 52(12):1279-92, 1994.

Savalle, W. P.; Weijs, W. A.; James, J. \& Everts, V. Elastic and collagenous fibers in the temporomandibular joint capsule of the rabbit and their functional relevance. Anat. Rec., 227(2):159-66, 1990

Siebelt, M.; Groen, H. C.; Koelewijn, S. J.; de Blois, E.; Sandker, M.; Waarsing, J. H.; Müller, C.; van Osch, G. J.; de Jong, M. \& Weinans, $H$. Increased physical activity severely induces osteoarthritic changes in knee joints with papain induced sulfate-glycosaminoglycan depleted cartilage. Arthritis Res. Ther., 16(1):R32, 2014.

Tavakkoli Jou, M. Mandibulofacial Development in Experimental Arthritis of the Juvenile Temporomandibular Joint. Thesis. San Francisco, University of California at San Francisco, 1994.

Tollison, C. D.; Satterthwaite, J. R. \& Tollison, J. W. Practical Pain Management. 30th ed. Philadelphia, Lippincott Williams \& Wilkins, 2002.

Tsiklakis, K.; Syriopoulos, K. \& Stamatakis, H. C. Radiographic examination of the temporomandibular joint using cone beam computed tomography. Dentomaxillofac. Radiol., 33(3):196-201, 2004.

Yang, F. \& Shi, Z. A study on papain-induced osteoarthritis in rabbit temporomandibular joint. Hua Xi Kou Qiang Yi Xue Za Zhi, 20(5):330$2,2002$.

Corresponding author:

Nilton Alves

Faculty of Dentistry

Universidad de La Frontera

Avda. Francisco Salazar 1145

PO BOX 54-D,

Temuco

CHILE

E-mail: nilton.alves@ufrontera.cl

Received: 13-11-2017

Accepted: 04-02-2018 